\title{
EFFECTIVITY OF NIPAH (Nypa fruticans) EXTRACT ON (Aedes aegypti) LARVAE IN BRACKISH WATER
}

\author{
$\operatorname{Rady}^{1}{ }^{*}$, Irwan Effendi $^{2}$, F. Feliatra ${ }^{2}$ \\ ${ }^{1}$ Student of The Faculty of Fisheries And Marine Science University of Riau, Pekanbaru \\ ${ }^{2}$ Lecturer at the Faculty of Fisheries And Marine Science University Riau, Pekanbaru \\ *rady2267@ student.unri.ac.id
}

\begin{abstract}
The most commonly used method of vektor control is temephos (the synthetic larvicide). Currently in some areas there has been resistance of aedes aegypti larvae to temephos, so that natural larvicide is required as an alternative. Nypa exctract contains flavonoid compounds that are respiratory toxins that can kill aedes aegypty larvae.This research was conducted in January - February 2019. The purpose of this study was to determine the inhibitory power of nipah extract against larvae in brackhish water. The results of this study are expected to increase knowledge and provide information about the pontential of nipah as a soursce of bioactive compounds. The method used is the experimental method, where the location of the research sampel was obtained at one sampling location point in the Sungai Kayu Ara village, Siak Riau province. The results showed that the average mortality of larvae in nipah laeves in the $60^{\text {th }}$ minute was $55,80,100$ and $100 \%$. While root extracts have larvae deaths as many as 60 minutes, namely 100, 90, 90, and $100 \%$. For the average mortality of larvae at the root of nipah there are 60 minutes, which are 95, 100, 100 and $100 \%$. As wel as positive and negative controls as a comparison. So it can be compared to 3 administration of nipah extract both leaves, roots and midrib so that the three conncentrations used are better than the use of midrib extract compared to leaf and root extract. It can be concluded that the more concentration used the higher the mortality of larvae is the concentration of $12 \%$. For the concentration used the percentage of larvae mortality in the test media is as much as 6\%,9\% and $12 \%$. Every death of larvae has reristance to different bodies so that at the $30^{\text {th }}$ minute there is a difference in mortality of larvae wich a given concentration. The larvae species used are aedes aegyti larvae. The highest mortality of dead es was found in midrib extract and also positive controls. So that the death of larvae is very effective against the given solution has the same ability. The mortality of $A$. aegypti larvae were then analyzed using probit analysis to obtain LC50 (Lethal Concentration 50) and LT50 (Lethal Time 50) values. The results of the probit analysis of leaf, root and midrib extracts are the estimation of LC50 1.493, 2.618, 0.005. while leaf , root and midrib extracts at the LT50 estimate were $2.841,1.579,2.227$
\end{abstract}

Keyword: ara wood, Nypa fruticans, Aedes aegypti, LC50 and LT50

\section{PENDAHULUAN}

Nipah (Nypa fruticans) adalah sejenis palem yang banyak tumbuh di berbagai wilayah Indonesia. Tanaman tersebut banyak banyak tumbuh didataran rendah berair seperti di rawa-rawa, sekitar sungai, waduk, dan sepanjang garis pantai pasang surut. Sebagian besar tanaman

nipah tumbuh secara alami atau belum ada masyaratyang membudidayakan secara intensif, hal tersebut disebabkan karna manfaat nipah bagi masyarakatmasih terbatas pada pengunaan daun sebagai atap rumahdan anyaman dalam jumlah relatif kecil. Buah nipah merupakan hasil hutan 
yang sifatnya musiman dengan buah yang melimpah setiap musimnya. Sebagian besar nipah yang ada di Indonesia hanya digunakan sebagai tanaman konservasi, belum kearah tanaman industri (Afrizal dan Pato, 2017).

Pemberantasan nyamuk Aedes aegypti sangat sulit karena mereka memiliki kemampuan yang sangat kuat beradaptasi lingkungan yang membuat mereka sangat tangguh, bahkan gangguan akibat fenomena alam.Pengendalian yang paling sering dilakukan adalah dengan cara memberikan senyawa kimia pada lotion penolak nyamuk atau pemberian larvasida pada larva nyamuk. Larvasida yang sering digunakan adalah temephos (abate) (Fuadzy et al., 2015).Meskipun aman bagi manusia, temephos yang digunakan untuk mengendalikan larva $A$. aegypti nyatanya memberikan efek samping terhadap lingkungan. Organisme yang tidak ditargetkan pun dapat terkena efek dari temephos ini (Tennyson et al., 2013).

Beberapa tanaman dapat dijadikan sebagai larvasida. Larvasida yang berasal dari tanaman memiliki beberapa keuntungan dibandingkan dengan larvasida buatan antara lain dapat terurai dengan cepat oleh sinar matahari, udara, kelembapan dan faktor alami lainnya. Hal ini membuat larvasida alami memiliki resiko rendah terhadap pencemaran tanah, air dan udara. Selain itu karena berbahan dasar alami, larvasida alami memiliki tingkat toksisitas yang rendah bagi manusia, sehingga dapat aman digunakan dalam kehidupan sehari-hari.

Dalam tanaman nipah mengandung beberapa zat fitokimia, diantaranya adalah tanin, flavonoid, fenolik, saponin dan terpenoid (Lestari et al., 2016). Menurut penelitian yang telah dilakukan Astriani dan Widawati (2016), senyawa saponin, tanin dan flavonoid merupakan senyawa yang berperan penting dalam membunuh larva A.aegypti. Oleh karena itu, ekstrak nipah memiliki potensi sebagai larvasida alami terhadap mortalitas larva nyamuk A.aegypti. Sehubungan dengan uraianuraian yang telah dijelaskan serta belum pernah dilakukan penelitian ini, maka penulis tertarik untuk melakukan penelitian dengan judul "Uji Efektivitas Ekstrak Nipah (Nypa fruticans) Terhadap Larva Nyamuk Aedes aegypti di Air Payau $"$.

Tujuan dari penelitian ini adalah untuk mengetahui daya hambat ekstrak nipah terhadap jentik nyamuk di air payau. Hasil penelitian ini diharapkan dapat menambah pengetahuandan memberikan informasi mengenai potensinipah sebagai sumber senyawa bioaktif.

\section{METODE PENELITIAN}

Penelitian ini dilaksanakan dari bulan Febuari - Maret 2019 di Laboratorium Mikrobiologi Laut, Jurusan Ilmu Kelautan dan Laboratorium Kimia Ilmu Kelautan, Fakultas Perikanan dan Kelautan,Universitas Riau.

Bahan-bahan yang digunakan dalam penelitian ini adalah daun, pelepah dan akar nipah (Nypa fruticans). Tumbuhan nipah ini diambil dari Desa Sungai Kayu Ara, Kabupaten Siak, Provinsi Riau. Nipah yang diambil di bawa ke Laboratorium Mikrobiologi Laut, Universitas Riau.Air payau yang digunakan sebagai tempat media larva nyamuk, alkohol adalah sebagai pelarut ekstrak nipah yang di uji sedangkan aquades digunakan untuk membersihkan semua alat dan bahan yang digunakan saat penelitian.

Pengukuran kualitas air dilakukan dengan mengukur aspek fisika dan kimia. Parameter fisika meliputi suhu dan salinitas, sedangkan parameter kimia yang diukur adalah pH.Pengukuran kualitas perairan dilakukan di tiga titik perairan.

Pembuatan ekstrak nipah dilakukan di Laboratorium Mikrobiologi Laut, dan Laboratorium Kimia Jurusan Ilmu Kelautan, Fakultas Perikanan dan 
Kelautan,Universitas Riau. Sampe lkemudian diambil beberapa daun pelepah batang dan akar untuk ditimbang di Laboratorium dengan menggunakan timbangan analitik. Selanjutnya sampel yang sudah ditimbang sebanyak 10 gram lalu dipotong halus-halus untuk dihaluskan dengan menggunakan alu mortar penghalus daun, pelepah dan akar tersebut.

Sampel yang telah halus kemudian ditetesi sedikit demisedikit alkohol secukupnya untuk pembuatan air larutan sampel tersebut. Selanjutnya setelah daun ditumbuk halus-halus baru dilakukan pemerasan untuk pengambilan ekstrak daun, pelepah dan akar nipah tersebut, pemisahan ampas dengan ekstrak nipah dilakukan dengan mumggunakan saringan.

Penyediaan jentik nyamuk ini diawali dengan mencari biakanjentik nyamuk yang ada diselokan atau parit dipinggir jalan Bina Krida dekat kampus Universitas Riau, Kota Pekanbaaru. Biakan jentik nyamuk didapatkan dari tempat yang tersedia di daerah Kota Pekanbaru. Biakan jentik nyamuk yang didapatkan lalu dibawa ke Laboratorium.

Penyiapan media uji diawali dengan pembuatan media air laut,dan air tawar yang dicampurkan untuk mendapatkan air payau yang diinginkan. Sebanyak $3 \mathrm{ppt}$ untuk penyiapan air payau dengan menggunakan 10 literair tawar dandiambil air laut sebanyak $\pm 1,200 \mathrm{ml}$ dengan salinitas $25 \%$ yang dimasukan kedalam suatu wadah besar air tersebut diaduk agar tercampur sempurna.Selanjutnya media uji dituang ke dalam botol sampelyang berukuran $150 \mathrm{ml}$ tetapi hanya $100 \mathrm{ml}$ media uji yang digunakan. Untuk itu media uji digunakan sebanyak 15 botol sampel untuk dimasukan kedalam botol sampel tersebut.Setiap sampel memiliki 3 konsentrasi yaitu 6,9 dan 12\% sedangkan larutannya yang digunakan yaitu ekstrak nipah, Abate $1 \%$ dan kontrol negatif. Selanjutnya pengambilan jentik nyamuk dilakukan dengan menggunakan pipet tetes.
Kemudian masukan larva nyamuk kedalam botol sampel sebanyak 20 ekor larva nyamuk. Untuk menghitung perbandingan jumlah air tawar dan air laut untuk mendapatkan air payau bersalinitas $3 \%$, dapat digunakan dengan rumus (Nurdin, 2017).

Uji toksisitas ekstrak nipah terhadap kematian jentik nyamukyaitu dilakukan dengan metode eksperimen. Toksisitas pada ekstrak nipah(daun, pelepah, akar) dengan konsentrasi 6\%, 9\% dan $12 \%$ serta adanya kontrol positif dan kontrol negatif sebagai perbandingan diletakkan pada uji sampel dan ada juga kontrol. Masingmasing sampel berisi 15-20 ekor jentik nyamuk Aedes aegypty dengan pengulangan sebanyak 3 kali. Setiap perlakuan dilakukan pengamatan terhadap jumlah mortalitas jentik nyamuk, tiap-tiap kelompok perlakuan pada masing-masing konsentrasi dalam waktu 24 jam dengan interval waktu selama 2 jam yaitu dengan waktu 15, 30, 45, 60, dan 120menit dengan cara menghitung A.aegypti yang mati ditiap patokan dengan waktu yang dilakukan pengamatan yaitu pengulangan selama dua hari. Angka konsentrasi yang diambil yaitu sebanyak $6 \%, 9 \%$ dan $12 \%$ pada kosentrasi tersebut ekstrak nipah bisa menghambat kematian jentik nyamuk.

Data yang diperoleh disajikan dalam bentuk tabel dan grafik. Selanjutnya data dianalisis secara deskriptif. Untuk melihat adanya perbedaan antar perlakuan, selanjutnyadapat dilakukan Uji ANOVA untuk melihat nilai sigtifikannya dengan menggunakan Uji lanjut LSD. Nilai LC50 dianalisis menggunakan uji probit. Seluruh data yang diperoleh dianalisis dengan menggunakan program SPSS software versi 23.

\section{HASIL DAN PEMBAHASAN Kondisi Umum Lokasi Penelitian}

. Desa Lalang, Kecamatan Sungai

Apit, Kabupaten Siak terletak pada posisi $1^{\circ} 2^{\prime} 0^{\prime \prime}-1^{\circ} 6^{\prime} 62^{\prime \prime}$ Lintang Utara dan dan 
$102^{\circ} 10^{\prime}$ 0"- $102^{\circ} 13^{\prime} 35^{\prime \prime}$ Bujur Timur. Secara umum Desa Lalang mempunyai batas-batas daerah yaitu sebelah Utara berbatasan dengan Desa Sungai Kayu Ara, sebelah Selatan berbatasan dengan Desa Mengkapan, sebelah Barat berbatasan dengan Desa Parit II, Desa Teluk Masjid dan Desa Perincit dan sebelah Timur berbatsan dengan Selat Malaka. Kondisi perairan di Desa Sungai Kayu Ara, memiliki pontensi hutan mangrove yang dijaga dan dilestarikan agar terhindar dari abrasi laut dan kerusakan ekosistem mangrove. Ekosistem mangrove sangat berperan penting dalam mendukung kehidupan organisme atau biota yang hidup didalamnya. Perairan laut ini juga dimanfaatkan untuk jalur tranportasi kapal, aktivitasnelayan, aktivitas masyarakat, dan lain sebagainya.

\section{Parameter Kualitas Perairan Sungai Kayu Ara}

Kondisi suatu perairan yang baik dan normal akan mendukung kehidupan suatu kondisi hutan nipah dalamnya. Pengukuran kualitas perairan ini bertujuan untuk melihat kondisi hutan mangrove tersebut yang tumbuh diperairan tersebut secara normal dan tidak ada sakit. Secara umum pertumbuhan hutan nipah maupun mangrove dipengaruhi oleh salinitas, $\mathrm{pH}$, suhu,dan sebagainya. Hasil pengukuran parameter kualitas perairanyang dilakukan dilokasi pengambilan sampel tersebut dapat dilihat pada Tabel 1.

Tabel 1. Kualitas Perairan Muara Sungai Kayu Ara

\begin{tabular}{llccc}
\hline No & Parameter & Nilai Pengamatan & Baku Mutu & \multicolumn{2}{c}{ Satuan } \\
\hline 1 & Salinitas & 25 & Alami & Ppt \\
2 & pH & $5-6$ & $6-9$ & - \\
3 & Suhu & $28-30$ & Alami & ${ }^{\circ} \mathrm{C}$ \\
\hline
\end{tabular}

Berdasarkan Tabel 1, dapat dilihat bahwa salinitas perairan saat pengambilan sampel adalah $25 \mathrm{ppt}$, sedangkan derajat keasaman $(\mathrm{pH})$ dengan kisaran 5-6, untuk suhu perairan berkisar antara $28-30{ }^{\circ} \mathrm{C}$.

\section{Toksisitas Ekstrak Nipah Terhadap Larva Nyamuk}

Toksisitas merupakan sifat relatif dari suatu zat kimia, dalam kemampuannya menimbulkan efek berbahaya atau penyimpangan mekanisme biologi pada suatu organisme. Toksisitas dipengaruhi oleh beberapa faktor, antara lain komposisi dan jenis toksikan, konsentrasi toksikan, durasi dan frekuensi pemaparan, sifat lingkungan, dan spesies biota penerima. Tingkat toksisitas suatu tanaman dinilai berdasarkan tingkat mortalitas bahan uji. Pengamatan dilakukan selama 1 jam dari awal percobaan yaitu dengan menghitung waktu 0 menit, 15 menit, 30 menit, 45 menit, dan 60 menit jumlah larva $A$. aegyptiyang mengalami kematian. Penghitunganjumlah kematian larva dilakukan pada masing-masing konsentrasi ekstrak nipah, kontrol positif, dan kontrol negatif. Hasil penghitungan jumlah kematian larva setelah 1 jam pengamatan dapat dilihat pada tabel 2 .

Tabel 2. Angka Kematian Kumulatif (\%) Larva Nyamuk Pada Media Uji yang dibubuhkan Ekstrak Daun Nipah

\begin{tabular}{cccccc}
\hline Konsentrasi Ekstrak & 0 Min & 15 Min & 30 Min & 45 Min & 60 Min \\
\hline $6 \%$ & 0 & 5 & 15 & 25 & 55 \\
$9 \%$ & 0 & 10 & 45 & 55 & 80 \\
$12 \%$ & 0 & 10 & 30 & 95 & 100 \\
Kontrol $(+)$ & 0 & 70 & 90 & 95 & 100
\end{tabular}




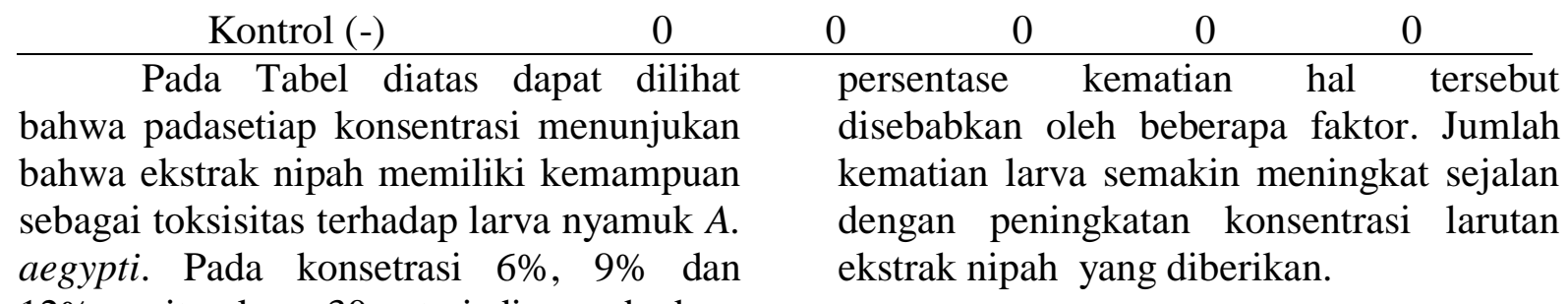
$12 \%$ menit ke 30 terjadi perbedaan

Tabel 3. Angka Kematian Kumulatif (\%) Larva Nyamuk pada Media Uji yang diBubuhkan Ekstrak Akar Nipah

\begin{tabular}{|c|c|c|c|c|c|}
\hline Konsentrasi Ekstrak & $0 \mathrm{Min}$ & $15 \mathrm{Min}$ & 30 Min & $45 \mathrm{Min}$ & $60 \mathrm{Min}$ \\
\hline $6 \%$ & 0 & 15 & 75 & 75 & 90 \\
\hline $9 \%$ & 0 & 15 & 70 & 85 & 90 \\
\hline $12 \%$ & 0 & 15 & 90 & 95 & 100 \\
\hline Kontrol (+) & 0 & 75 & 95 & 100 & 100 \\
\hline Kontrol (-) & 0 & 0 & 0 & 0 & 0 \\
\hline
\end{tabular}

Berdasarkan pada hasil Tabel 3, persentase kematian larva nyamuk untuk ekstrak nipah pada media uji memiliki angka kematian yang sangat berbeda. Pada konsetrasi $6 \%, 9 \%$ dan $12 \%$ menit ke 30 dan 45 terjadi perbedaan persentase kematian hal tersebut disebabkan oleh beberapa faktor. Pada konsentrasi kontrol negatif tidak memiliki angka kematian yaitu $0 \%$ disebabkan tidak adanya campuran apapun. Kematian larva nyamuk mati $100 \%$ terdapat pada konsentrasi6\%, $9 \%, 12 \%$, dan diikuti kontrol positif pada menit ke 60 yaitu sebanyak 20 ekor.

Tabel 4. Angka Kematian Kumulatif (\%) Larva Nyamuk pada Media Uji yang di Bubuhkan Ekstrak Pelepah Nipah.

\begin{tabular}{cccccc}
\hline Konsentrasi Ekstrak & 0 Min & 15 Min & 30 Min & 45 Min & 60 Min \\
\hline $6 \%$ & 0 & 30 & 55 & 85 & 95 \\
$9 \%$ & 0 & 40 & 50 & 100 & 100 \\
$12 \%$ & 0 & 40 & 65 & 100 & 100 \\
Kontrol (+) & 0 & 85 & 95 & 100 & 100 \\
Kontrol (-) & 0 & 0 & 0 & 0 & 0 \\
\hline
\end{tabular}

$\begin{array}{ccr}\text { Berdasarkan Tabel } 4 & \text { terlihat } \\ \text { persentase kematian larva nyamuk }\end{array}$ A.aegypti terdapat pada menit ke 60 yang paling tinggi yaitu $100 \%$ terdapat pada konsentrasi kontrol (+), lalu diikuti $6 \%$, $9 \%$, dan $12 \%$ sedangkan persentase nilai terendah pada larva nyamuk yaitu terdapat pada menit ke 60 pada konsentrasi kontrol() yaitu $0 \%$.Pada konsetrasi $6 \%, 9 \%$ dan
$12 \%$ menit ke 30 terjadi perbedaan persentase kematian hal tersebut disebabkan oleh beberapa faktor.Pada pengamatan hari pertama ke dua dan ke tiga maka dapat dikatakan semakin banyak konsentrasi yang digunakan semakin bagus tingkat kematian larva nyamuk tersebut. Untuk lebih jelasnya dapat dilihat pada Gambar 1. 


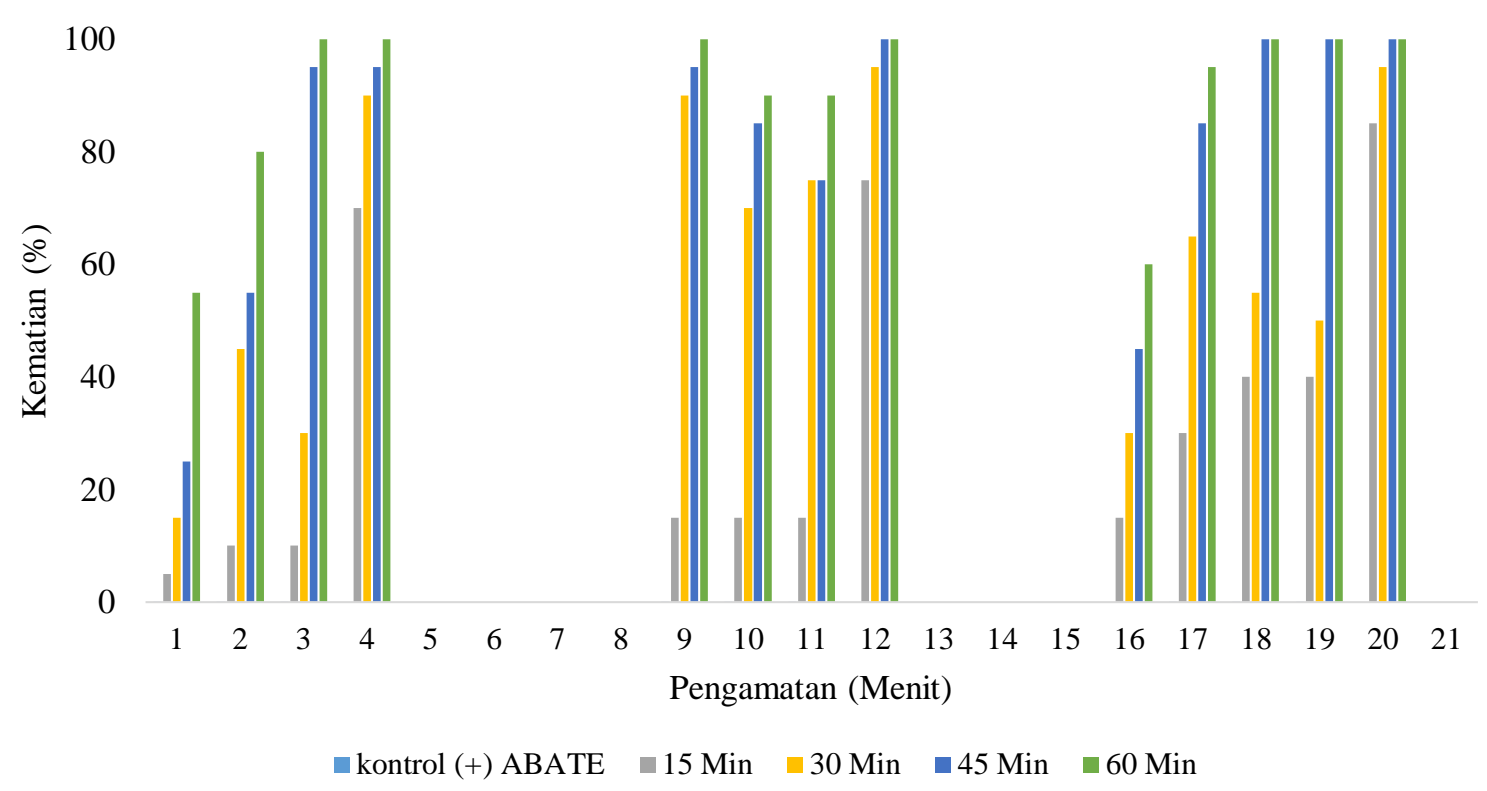

Gambar 1. Mortalitas Larva (A.aegypti) pada Konsentrasi Pelepah(Nypa fruticans)

Pada Gambar 1, menjelaskan bahwa larva nyamuk lebih cepat mati pada penggunaan ABATE dengan konsentrasi positif yaitu pada waktu (menit) yang didapatkan sebesar 70, 90, 95 dan $100 \%$. Konsentrasi yang rendah terdapat pada kontrol negatif yaitu sebesar0\% untuk ekstrak daun nipah didapatkan pada menit ke 45 yaitu 35, 55, 95 dan 95. Untuk hasil presentase kematian larva nyamuk pada akar yaitu didapatkan pada kontrol positif (ABATE) 75, 95, 100 dan 100\%, untuk ekstrak akarnya didapatkan pada menit ke 45 terdapat kematian larva nyamuk yaitu 75,8595 dan $100 \%$. Berdasarkan hasil gambar diatas menjelaskan bahwa larva nyanmuk lebih cepat mati pada penggunaan ABATE dengan konsentrasi positif yaitu pada waktu (menit) yang didapatkan sebesar 85 95, 100 dan 100\%, untuk pelepah ekstraknya didapatkan pada menit ke 45 yairtu 85, 100, 100 dan 100\%. Sehingga pengunaan ekstrak nipah sangat berefektif terhadap kematian larva nyamuk. Sehingga terdapat perbedaan antar perlakuaan yang diberikan pada masingmasing konsentrasi.
Hal ini menunjukkan bahwa semua presentase kematian kosentrasi larutan uji berpengaruh terhadap mortalitas larva nyamuk A.aegyptidengan waktu pengamatan bahkan pada perlakuan A1 dan A2 A3, A4 dan A5 seluruh larva A.aegypti sudah mengalami kematian pada waktu 60 menit dengan waktu 1 jam pengamatan. Pada perlakuan larutan uji lainnya, mortalitas larva A.aegypti juga memiliki jumlah mortalitas larva yang paling tinggi pada menit ke 60 dengan waktu 1 jam pengamatan pertama, kedua dan ketiga hal ini dapat di asumsikan bahwa presentase kematian larva nyamuk yang terdapat dalam ekstrak Nypa fruticans dan juga kontrol positif bekerja aktif sehingga menyebabkan banyak larva $A$. aegypti yang mati.

Rerata mortalitas larva A.aegypti selanjutnya dianalisis menggunakan analisis probit untuk memperoleh nilai LC50 (Lethal Concentration 50) dan LT50(Lethal Time 50). Hasil analisis probit dapat dilihat pada Tabel 5 dibawah ini. 
Tabel 5. Nilai LC50 dan LT 50 Ekstrak (Nypa Fruticans)terhadap larva nyamuk (A.aegyti)pada daun, akar, dan pelepah nipah.

\begin{tabular}{|c|c|c|c|}
\hline \multirow{2}{*}{ Probability } & \multicolumn{3}{|c|}{ 95\% Confidence Limits for Extract } \\
\cline { 2 - 4 } & Estimate & Estimate & Estimate \\
\hline LC50 & 1,493 & 2,618 & 0,005 \\
\hline \multirow{2}{*}{ LT50 } & 2,841 & 1,579 & 2,227 \\
\hline
\end{tabular}

Berdasarkan nilai probit pada uji LC50 dan LT50 pada daun nipah mendapatkan nilai memperkirakan untuk nilai LC 50 yaitu 1,493 sedangkan pada LT 50 diperkirakan nilainya yaitu sebesar 2,841 .

Berdasarkan nilai probit pada uji LC50 dan LT50 pada akar mendapatkan nilai memperkirakan untuk nilai LC 50 yaitu 2,618 sedangkan pada LT 50 diperkirakan nilainya yaitu sebesar 1,579.

Berdasarkan nilai probit pada uji LC50 dan LT50 pada pelepah mendapatkan nilai memperkirakan untuk nilai LC 50 yaitu 0,005 sedangkan pada LT 50 diperkirakan nilainya yaitu sebesar 2,227.

Berdasarkan hasil yang didapatkan pada uji ekstrak nipah, dengan konsentrasi $6 \%, 9 \%$, dan $12 \%$ serta kontrol positif dan juga kontrol negatif sudah dapat membunuh $100 \%$ larva. Hasil ini menjadikan konsentrasi 6\%, 9\%, dan 12\% dapatsebagai pedoman untuk melihat efektivitas ekstrak nipah terhadap larva nyamuk (A. aegypti) dengan konsentrasi yang lebih kecil atau dengan konsentrasi yang lebih besar.

Ekstrak nipah alkohol konsentrasi $70 \%$ dijadikan sebagai titik tengah dalam penentuan deretan konsentrasi pada uji yang dilakukan. Ekstrak nipah yang akan diuji adalah ekstrak nipah dengan deretan lima konsentrasi berbeda. Deretan konsentrasi yang dipakai adalah 6\%, 9\%, dan 12\%.Pada kelompok kontrol negatif tidak ditemukan larva yang mati, hal ini membuktikan bahwa kematian larva pada kelompok uji tidak disebabkan oleh faktor lain. Pada kontrol negatif hanya didimasukan kemedia uji yaitu air biasa atau air tawar.

Pada konsetrasi 6\%, 9\% dan 12\% terjadi perbedaan persentase kematian larva nyamuk yang mana hal tersebut disebabkan oleh beberapa faktor yaitu kelembaban udara, suhu dan cahaya matahari yang masuk ke dalam ruang yang menyebabkan ruangan tersebut tidak stabil serta ketahanan individu larva tersebut berbedabeda. Pada setiap perlakuan yang diberikan sehingga memilki ketahanan pada tubuh larva nyamuk tidak kuat dalam dibubuhi pemberian konsentrasi tersebut. Larva nyamuk yang ada di botol media uji memilki ukuran yang berbeda dari kecil hingga besar sehingga larva nyamuk yang di media uji memiliki ketahanan hidup yang berbeda-beda.

Menurut (Nadila et al., 2017) perbedaan ini kemungkinan terjadi diakibatkan oleh beberapa hal. Pertama, bahan uji menggunakan ekstrak dari tumbuhan dengan spesies yang berbeda meskipun pada genus yang sama kemungkinan akan menyebabkan kemiripan pada metabolit sekunder nipah. Kedua, perbedaan kemungkinan diakibatkan oleh faktor biologi berupa lokasi asal tumbuhan akan mempengaruhi kadar metabolit sekunder nipah. Selain itu terdapat faktor kimia yaitu metode ekstraksi dan juga pelarut yang digunakan dalam ekstraksi akan berpengaruh terhadap kondisi ekstrak dan juga kemampuan larvasidanya. Pada penelitian terdapat faktor yang dapat mengakibatkan kematian larva. Faktor tersebut adalah suhu sehingga 
pada penelitian dilakukan pengendalian terhadap suhu ruangan tempat penelitian. Suhu dipertahankan pada kisaran suhu ruangan yang terbuka dengan kisaran suhu ruangan yaitu $30^{\circ} \mathrm{C}$.

Hasil penelitian yang terlihat pada Tabel 5, 6 dan 7 menunjukkan bahwa terdapat perbedaan kematian larva $A$. aegpyti antar perlakuan dengan berbagai konsentrasi. Hasil penelitian menunjukkan konsentrasi ekstrak nipah yang paling efektif dalam membunuh larva adalah $12 \%$ dengan persentase kematian yaitu pada waktu 60 menit larva nyamuk mati semua yaitu sebayak 20 ekor, baik itu diperlakuankontrol positif kontrol negatif dan juga pada ekstrak nipah tersebut.

Pada hasil dan grafik di atas sehingga dapat disimpulakan bahwa kematian larva nyamuk pada penggunaan ekstrak nipah lebih bagus pada ekstrak pelepah dibandingkan akar dan daun.

Perbandingan antar kelompok perlakuan menunjukkan bahwa semua konsentrasi memiliki perbedaan nilai signifikan, yaitu pada daun, akar dan pelepah pada ekstrak nipah tersebut. Sehingga nilainya yang didapat tidak signifikan menunjukkan hasil yang tidak bermakna.

Uji beda antar kelompok diketahui dari nilai signifikan.jika nilai $\alpha$ nya lebih kecil dar nilai 0.05 maka dapat disimpulkan terdapat perbedaan bermakna pada jumlah larva yang mati antar kelompok perlakuan yang dibandingkan.

Pada kontrol positif dengan menggunakan ABATE0,01\% dijadikan sebagai kontrol positif pada penelitian ini. Pemberian Temephos $0,01 \%$ sehingga mengakibatkan kematian 98\% - 100\% larva, tetapi pada penelitian ini didapatkan hasil kematian larva dengan rata-rata kematian yang sangat berbeda dalam kosentrasiyang digunakan.Abate menunjukkan respon mortalitas $100 \%$ setelahlarva nyamuk A.aegypti kontak selama 1 jam. Hal ini menunjukkan bahwa kematian larva A.aegypti pada larutan uji kemungkinan disebabkan oleh adanya senyawa - senyawa yang bersifat toksik yang mampu membunuh jentik nyamuk tersebut.

Penelitian ini dilakukan untuk mengetahui efektivitas ekstrak nipah dalam mengendalikan jentik nyamuk A.aegyptidi uji penelitian. Pada penelitian ini digunakan ekstrak nipah yang telah diekstraksi dengan metode experimen dengan menggunakan pelarut alkohol $70 \%$ yang dimaksudkan agar didapatkan kandungan flavonoid dan limonoid yang terkandung dalam nipah yang diduga memiliki efek terhadap larva Aedes sp.

Menurut (Isfarani Nadilaet al., 2017) menyatakan selain itu terdapat faktor kimia yaitu metode ekstraksi dan juga pelarut yang digunakan dalam ekstraksi akan berpengaruh terhadap kondisi ekstrak dan juga kemampuan larvasidanya.

Penelitian yang dilakukan oleh Habib (2018) menyatakan bahwa di Kecamatan Koto Tangah telah terjadi penurunan kerentanan A. aegypti terhadap temephos menjadi toleran yaitu dengan persentase kematian akibat temephos 0,012 $\mathrm{mg} / \mathrm{L}$ adalah $87,50 \%$.

Pada penelitian ini, dilakukan pengecilan volume wadah dengan dengan mengggunakan wadah yang sama jenisnya dengan tempat perkembangbiakan jentik nyamuk Aedes sp yang lebih kecil yang bertujuan untuk mengefesienkan penggunaan ekstrak yang terbatas. Kemudian, dilakukan pengukuran suhu, $\mathrm{pH}$ dan salinitas pada tempat perindukan larva Aedes sp. Suhu larutan merupakan faktor pengaruh dalam pertumbuhan dan perkembangan larva nyamuk Aedes sp, hasil pengukuran pada penelitian ini menunjukkan suhu ekstrak $28^{\circ} \mathrm{C}-30^{\circ} \mathrm{C}$.

Menurut (Noorhajati at el., 2013) Pada pengujian biolarvasida larva ini digunakan kontrol positif yakni bubuk ABATE 100 ppm sehingga dapat kita ketahui langsung perbandingan daya anti larva nyamuk A. aegypti antara ABATE 
sebagai kontrol positif dibandingkan dengan fraksi-fraksi ekstrak nipah tersebut.

Hasil perhitungan terhadap jumlah larva nyamuk yang berada pada tempat sampel baik sebelum dan setelah pemberian ekstrak nipahdiperkuat dengan hasil analisis secara statistik dengan menggunakan uji Anova. Beradasarkan data pada tabel diatas 2, 3 dan 4 diperoleh bahwa hasil uji Anova memiliki perbedaan sebesar dengan signifikannya.003pada daun nipah. sedangkan pada ektrak akar nilai signifikannya .004dan untuk yang di pelepah terdapat nilai signifikannya .001. Karena nilai sig $<0,05$ maka dapat dinyatakan berbeda nyata (tidak homogen) terdistribusi tidak normal maka dilakukan Uji lanjut yaitu dengan menggunakan Uji LSD. Rata-rata jumlah larva nyamuk sebelum dan setelah pemeberian ekstrak nipah maka $\mathrm{H} 0$ ditolak, dan $\mathrm{H} 1$ nya diterima.

Ekstrak Nypa friticans daun, pelepah dan akar mengandung senyawa terpenoid yang termodifikasi alkaloid yang aktif. Senyawa tersebut memiliki kemampuan bekerja sebagai racun kontak yang baik karena kemampuannya untuk menembus organ serangga. Pada larva senyawa tersebut bekerja baik sebagai racun kontak maupun racun perut, pada sistem saraf senyawa aktif ini bekerja pada ganglia sistem syaraf pusat. Alkaloid dan terpenoid juga dapat menyebabkan gangguan sistem pencernaan karena senyawa ini bertindak sebagai racun perut yang masuk melalui mulut larva (Taher dan Papuangan., 2015).

Menurut (Fayemiwo et al., 2014) perbedaan LC50 ini dipengaruhi oleh beberapa faktor, diantaranya adalah polpulasi yang digunakan, metodologi, konsentrasi minyak atsiri yang digunakan dan tempat asal dari tanaman yang digunakan sebagai minyak atsiri.

Menurut (Riyadiet al, 2018) berdasarkan analisis probit yang terlihat pada Tabel 5, 6 dan 7, didapatkan LT50 dari ekstrak daun nipah adalah 2,841\% dengan batas bawah 2,288\% dan batas atas,3,220\%. Pada uji probit pada ekstrak akar didapatkan sebesar 1,579\%dengan batas bawah $1,087 \%$ dan batas atas $1,972 \%$. Sedangkan uji probit pada ekstrak pelepah nipah diperkirakan adalah sebesar 2,227dengan batas bawah 2,025 \% dan batas atas, $2,394 \%$. Nilai ini berarti bahwa konsentrasi ekstrak nipah yang dapat membunuh $50 \%$ larva adalah konsentrasi $6 \%, 9 \%$, dan $12 \% \%$ dengan batas interval dari 15, 30, 45, dan 60 .

LC50 dari ekstrak daun, pelepah dan akar nipah yang didapatkan dari analisis probit pada penelitian ini adalah $1,493 \%$ dengan batas bawah $0 \%$ dan batas atas $0 \%$. Nilai ini berarti bahwa konsentrasi ekstrak daun, pelepah dan akar niapah yang dapat membunuh 50\% larva adalah konsentrasi 1,493\% dengan batas interval dari $0 \%$ hingga $0 \%$. Hal ini membuktikan ekstrak nipah yang digunakan dalam penelitian ini tidak efektif sebagai larvasida.

Temephos memiliki LC50 terhadap larva nyamuk A.aegypti sebesar 0.001 ppm (Lariska et al., 2016). Meskipun terdapat perbedaan yang cukup besar pada LC50 dan LT50 antara minyak ekstrak nipah dan temephos, larutan nipah bisa dijadikan alternatif sebagai larvasida alami terhadap larva nyamuk A.aegypti. Dibandingkan temephos minyak atsiri memiliki tingkat toksisitas yang rendah terhadap manusia dan ekosistem (Faraco et al., 2016) .

Berdasarkan Uji Statistik Anova pada Daun yang telah dilakukan didapatkan bahwa terdapat perbedaan yang signifikan antar perlakuan yang diberikan terhadap tingkat kematian larva nyamuk dengan nilai signifikan yaitu .003 yang berarti $<0.05$ maka dapat disimpulkan bahwa Ho ditolak dan $\mathrm{H} 1$ diterima artinya ekstrak nipah tersebut (Daun, Aran dan Pelepah) memiliki kemampuan dapat membunuh larva nyamuk $A$. aegypti, berdasarkan $\mathrm{F}$ hitung dan $\mathrm{F}$ tabel terdapat perbedaan 
signifikan antara perlakuan yang diberikan pada derajat keyakinan 95\%, dengan demikian dilakukan uji lanjut menggunakan LSD dapat dilihat $\mathrm{F}$ hitung 6.372 lebih besar daripada $\mathrm{F}$ tabel 2.53 pada taraf nyata $5 \%$ dengan demikian rerata konsentrasi berbeda nyata dengan symbol $(*)$. Untuk lebih jelasnya bisa lihat di lampiran 7 .

Dan untuk Uji Statistik Anova pada akar yang telah dilakukan didapatkan bahwa terdapat perbedaan yang signifikan antar perlakuan yang diberikan terhadap tingkat kematian larva nyamuk dengan nilai signfikan yaitu .004 yang berarti $<0.05$ maka dapat disimpulkan bahwa Ho ditolak dan H1 diterima artinya ekstrak nipah tersebut (Daun, Akar dan Pelepah) memiliki kemampuan dapat membunuh larva nyamuk $A$. aegypti, berdasarkan $\mathrm{F}$ hitung dan $\mathrm{F}$ tabel terdapat perbedaan signifikan antara perlakuan yang diberikan pada derajat keyakinan 95\%, dengan demikian dilakukan uji lanjut menggunakan LSD dapat dilihat $F$ hitung 6.074 lebih besar daripada $\mathrm{F}$ tabel 2.53 pada taraf nyata $5 \%$ dengan demikian rerata konsentrasi berbeda nyata dengan symbol $\left({ }^{*}\right)$. Untuk lebih jelasnya bisa lihat di lampiran 8 .

Sedangkan untuk Uji Statistik Anova pada pelepah yang telah dilakukan didapatkan bahwa terdapat perbedaan yang signifikan antar perlakuan yang diberikan terhadap tingkat kematian larva nyamuk dengan nilai signifikan yaitu .001 yang berarti $<0.05$ maka dapat disimpulkan bahwa Ho ditolak dan H1 diterima artinya ekstrak nipah tersebut (Daun, Aran dan Pelepah) memiliki kemampuan dapat membunuh larva nyamuk $A$. aegypti, berdasarkan $\mathrm{F}$ hitung dan $\mathrm{F}$ tabel terdapat perbedaan signifikan antara perlakuan yang diberikan pada derajat keyakinan 95\%, dengan demikian dilakukan uji lanjut menggunakan LSD dapat dilihat $\mathrm{F}$ hitung 9.157 lebih besar daripada $\mathrm{F}$ tabel 2.53 pada taraf nyata 5\% dengan demikian rerata konsentrasi berbeda nyata dengan symbol $\left({ }^{*}\right)$. Untuk lebih jelasnya bisa lihat di lampiran 9. Dari ketiga ekstrak nipah yang digunakan untuk melihat kematian larva nyamuk dapa dilihat perbedaan antar uji statistik dari uji lanjut yang didapatkan. Sehingga pada penggunaan konsentrasi ektrak nipah lebih bagus dipelepah dibandingkan daun dan akar.

\section{KESIMPULAN DAN SARAN}

Berdasarkan hasil penelitian ini didapatkan bahwa ekstrak nipah memiliki efektivitas terhadap larva nyamuk $A$ aegypti. Apabila dibandingkan dengan ABATE (temephos) sebagai larvasida pada konsentrasi yang digunakan 6, 9 dan 12\% sehingga memiliki efek yang sama. Hasil penelitian ini menunjukan bahwa semakin tinggi konsentrasi ekstrak nipah yang diberikan, semakin banyak kematian larva nyamuk.

Untuk penelitian selanjutnya, disarankan untuk meneliti dengan penggunan pelarut yang lainnya dan juga waktu yang berbeda.

\section{UCAPAN TERIMA KASIH}

Pada kesempatan ini penulis menyampaikan ungkapan terima kasih kepada Didik Riyubas S.H., NurArifin, S.Pi., Mestika Yunas, A.Md.,Helvitri, S.Farm. Ungkapan terima kasih kepada Ayahanda dan Ibunda tercinta yang telah memberikan doa, dukungan moral dan material. Tidak lupa kepada teman IK015 atas kerjasama dan motivasinya dan kepeduliannya selama ini serta semua pihak yang telah membantu ini serta semua pihak yang telah membantu baik yang secara langsung dan tidak langsung dalam pelaksanaanpenelitian ini yang tidak dapat penulis sebutkan namanya satu persatu. 


\section{DAFTAR PUSTAKA}

1. Astriani, Ydan M. Widawati. (2016). Potensi Tanaman di Indonesia sebagai Larvasida Alami untuk Aedes aegypti.8(2):37-46.

2. Alrasyid,H., (2001). Pedoman Pengelolaan Hutan Nipah (Nypa fruticans) Secara Lestari. Puslitbang Hutan dan Konservasi Alam. Badan Litbang Kehutanan. Departemen Kehutanan. Bogar.

3. Bintang I.A.K, A.P. Sinurat dan T. Purwadaria. (2007). Penambahan ampas mengkudu sebagai senyawa bioaktif terhadap performans ayam broiler. JITV 12(1) :1-5.

4. Ditjenbun. (2006). Daftar Komoditi Binaan Direktorat Jendral PerkebunanBerdasarkan Keputusan Menteri Pertanian Nomor 511/KPTS/PD 310/9/2006.

5. Danarto, Y.C., S.A. Prihananto dan Z.A.Pamungkas., (2011). Pemanfaatan Tanin dari Kulit Kayu Bakau sebagai Pengganti Gugus Fenol pada Resin Fenol Formaldehid.Prosiding Seminar Nasional Teknik Kimia "Kejuangan".

6. Eldridge, F and J. D. Edman. (2012). Medical Entomology. USA : Departement of Entomology. Universitas of California.

7. Erliza, N., (2006). Ekstraksi Giberalin dari Akar Eceng Gondok. Skripsi Fakultas Kehutanan. Institut Pertanian Bogor.

8. Fuadzy, H., D. N. Hodijah., A. Jajang., dan M. Widawati. (2015). Kerentanan Larva Aedes Aegypti Terhadap Temefos di Tiga Kelurahan Endemis Demam Berdarah Dengue Kota Sukabumi. Buletin Penelitian Kesehatan. 43(1): 41-46.

9. Fayemiwo, K. A., Adeleke, M. A., Okoro, O. P., Awojide, S. H., Olufemi, I., Awoniyi. (2014). Larvicidal efficacies and chemical composition of essential oils of Pinus sylvestris and Syzygium aromaticum against es. Asian Pacific Journal of Tropical Biomedicine, 4(1), 30-34.

10. Faraco, A., Araujo, D. O., Ribeiro-paes, J. T., Deus, J. T. De. (2016). Larvicidal activity of Syzygium aromaticum (L.) Merr and Citrus sinensis ( L .) Osbeck essential oils and their antagonistic effects with temephos in resistant populations of Aedes aegypti, Memórias do Instituto Oswaldo Cruz, 111(7), 443-449.

11. Hamuna, B., Paulangan, Y.P.,dan Dimara,I. (2015). Kajian suhu permukaan laut menggunakan data satelit Aqua-MODIS diperairan Jayapura, Papua. Depik, 4(3), 160167.

12. Heriyanto, N.M. E. Subiandono dan E. Karlina. (2011). Potensi Dan Sebaran Nipah (Nypa Fruticans (Thunb.) Wurmb) Sebagai Sumberdaya Pangan (Potency And Distribution Of Nypa Palm (Nypa Fruticans (Thunb.) Wurmb) As Food Resource)).Pusat Litbang Konservasi dan Rehabilitasi. Bogor.

13. Kamal E., (2011). Fenologi mangrove (R. apiculata, R. mucronata dan R.stylosa) di pulau Unggas, Air Bangis Pasaman Barat, Sumatera Barat. Jurnal Natur Indonesia 14(1): 90-94.

14. Mukhriani. (2014). Ekstraksi, Pemisahan Senyawa, dan Identifikasi Senyawa UIN Alauddin Makassar. 
15. Nur El Fajri dan A. Kasry. (2013). Kualitas Perairaian Muara Sungai Siak Ditinjau dari Sifat Fisika-Kimia dan Makrozoobentos. Jurnal Berkala Perikanan Terubuk. 41(1) : 37-52.

16. Nadila, I, Istiana. Wydiamala, E. (2017). Aktivitas Larvasida Ekstrak Etanol Daun Binjai (mangifera caesia) Terhadap Larva Aedes aegypti. Berkala Kedokteran, 13(1) : 61-68.

17. Nurdin, S. (2017). Optimasi Pembentukan Bioflok dari Cheatoceros sp., Thalassiosira sp, dan Bakteri Probiotik Melalui Variasi Salinitas Secara In Vitro. Jurnal Bionature 18(2). Universitas Negeri Makassar.

18. Olayemi, I.K., I.C.J. Omalu., O. I.Famotele., S. P.Shegna., andB. Idris. 2010. Distribution of Larvae in Relation to Physico-Chemical Characteristics of Breeding Habitats in Minna, North Central Nigeria. Reviews in Infection. 1(1): 49-53.

19. Vernandos, A., dan N. Huda. (2008). Fermentasi Nira Nipah Menjadi Etanol Menggunakan Saccharomyces Cerevisiae. Skripsi. Universitas Riau, Pekanbaru.

20. Zamani, N.P., M. Gazali and I. Batubara. (2015). The Study of Tyrosinase and Antioxidant Activity of Xylocarpus Granatum Koenig Seed Kernel Extract toward Evidence Based Indigenous Knowledge from Togean Archipelago, Indonesia. J Marine Sci Res Dev 5: 168. doi:10.4172/2155- 9910.1000168. 